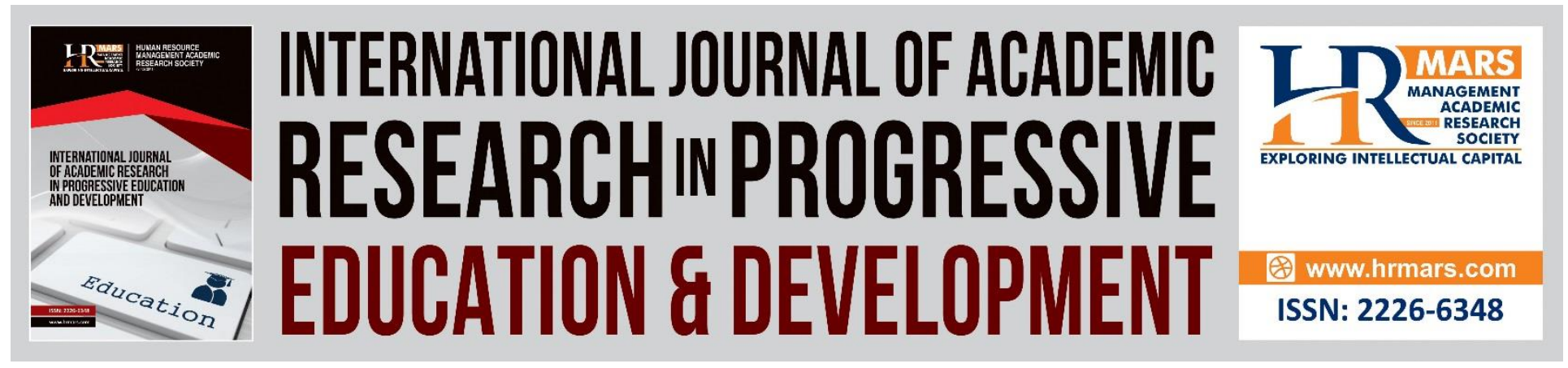

\title{
Career Decision Making among Malaysian University Students
}

\author{
Ahmad Aizuddin Md Rami, Siti Nadhirah Mohd Zaini \& Mohd Faiq Abd \\ Aziz
}

To Link this Article: http://dx.doi.org/10.6007/IJARPED/v10-i2/10189

DOI:10.6007/IJARPED/v10-i2/10189

Received: 11 April 2021, Revised: 14 May 2021, Accepted: 27 May 2021

Published Online: 18 June 2021

In-Text Citation: (Rami et al., 2021)

To Cite this Article: Rami, A. A. M., Zaini, S. N. M., \& Aziz, M. F. A. (2021). Career Decision Making among Malaysian University Students. International Journal of Academic Research in Progressive Education and Development, 10(2), 703-714.

Copyright: (C) 2021 The Author(s)

Published by Human Resource Management Academic Research Society (www.hrmars.com)

This article is published under the Creative Commons Attribution (CC BY 4.0) license. Anyone may reproduce, distribute, translate and create derivative works of this article (for both commercial and non-commercial purposes), subject to full attribution to the original publication and authors. The full terms of this license may be seen at: http://creativecommons.org/licences/by/4.0/legalcode

Vol. 10(2) 2021, Pg. 703 - 714

http://hrmars.com/index.php/pages/detail/IJARPED

JOURNAL HOMEPAGE

Full Terms \& Conditions of access and use can be found at http://hrmars.com/index.php/pages/detail/publication-ethics 


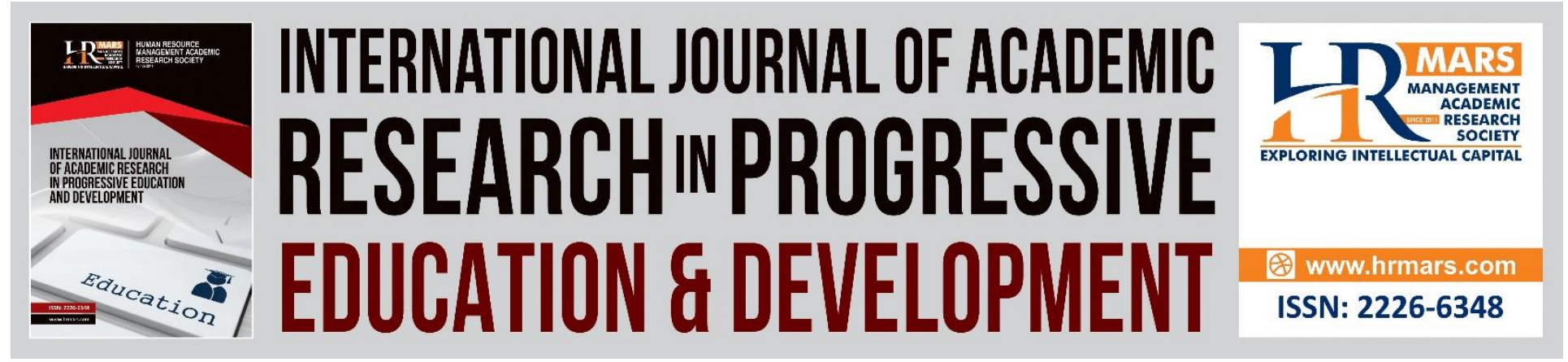

\title{
Career Decision Making among Malaysian University Students
}

\author{
Ahmad Aizuddin Md Rami, Siti Nadhirah Mohd Zaini \& Mohd Faiq \\ Abd Aziz \\ Faculty of Educational Studies, Universiti Putra Malaysia, 43400, Serdang Selangor, Malaysia \\ Email: ah.aizuddin@gmail.com,nadhirahzaini247@gmail.com,mohd_faiq@gmail.com
}

\begin{abstract}
Career decision making is a huge challenge for undergraduate students. Indeed, the challenges they encounter when making a career choice during the transition periods are common problems for university students. Hence, this quantitative study used a correlational research design to investigate the relationship between academic achievement and self-concept with career decision making among final year students in Universiti Putra Malaysia. A total of 171 final year students participated in the study. The academic achievement of the students was measured using the current CGPA. The Academic Self-Concept Scale (ASC) developed by Liu and Wang (2005) and Career Decision Scale (CDS) (Osipow et al., 1976) were administered to the sample to assess their self-concept and career decision, respectively. The study results show that there is no significant relationship between academic achievement and career decision making. Simultaneously, there is a significant relationship between academic self-concept toward career choice among undergraduate students. These findings add to our knowledge in helping students to make better decisions about their future careers by enhancing their academic self-concept. Keywords: Academic Achievement, Academic Self-Concept, Career Choice, Career Decision.
\end{abstract}

\section{Introduction}

Career decision making or career choices may be defined as a process-oriented model that examines how individuals decide or the situations that led to career choices (Levin et al., 2020). One of the most important decisions people make throughout their lives is career decisions, particularly for undergraduate students. Thus, the current study focuses on undergraduate students of Universiti Putra Malaysia (UPM) who are in their final year as they will face the working environment and culture after graduation.

According to the Graduates Statistics 2019 by the Department of Statistics Malaysia, the unemployment rate stayed at 3.9\% from 2018 until 2019. In terms of numbers, unemployed graduates in Malaysia increased 5.5\% in 2019, totalled 170.3 thousand compared to 161.3 thousand reported in 2018. This phenomenon can make university students more concerned 
about their career opportunities after graduation. They may perceive high levels of anxiety when they are expected to make decisions on the desired career. This stressful period can adversely affect the quality of their career decision and may lead to career indecision (Jang \& Lee, 2020). Career indecision refers to the failure to decide what occupation to seek. Students that had troubled in making career decision are students who are not ready for their future career. It is also highly likely that they will also experience stressful events at the workplace, job dissatisfaction, and dismissal.

The literature on exploring career decision-making for undergraduate students has drawn attention to various difficulties influencing their academic improvement and career advancement goals. The continuous integration of the students' abilities, motivations, and emotional experiences can develop career decision-making skills (Krannich et al., 2019). Therefore, the university plays a key role in providing a good learning environment for undergraduate students to prepare undergraduate students for their future career lives.

Although the relationship between academic achievement and academic self-concept has been extensively researched, there has been a lack of quantitative research examining the relationship of academic achievement and academic self-concept on career decision making in the same research studies. Indeed, the needs for this research focus on both students and learning institutions alike to better understand whether academic achievement and academic self-concept can help the students make a career decision. Hence, the main objective of this study is to investigate the relationship between academic achievement and self-concept with career decision making among final year students in Universiti Putra Malaysia (UPM).

\section{Literature Review \\ Career Decision Making}

In Malaysia, an increasing number of occupations, careers, and job pathways may influence the young adult's career choice since there are many important factors to be considered while choosing one's career path. The process of career selection is very complicated and requires numerous applications, such as knowledge, skills and experience related to career decision making (Storme \& Celik, 2018). A recent study by Abdullah et al. (2018) stated that university graduates in Malaysia often lack soft-skills and job-search skills affecting their career decision-making skills. According to Gati et al (2019), individuals with strong decision-making skills can have successful career development.

Indeed, Krannich et al (2019) confirmed one of the important aspects of the careerrelated decision-making process is information about the profession, concerned students' learning abilities, motivation, and emotional experiences. Making a career decision is a critical stage of a student's life in which a variety of considerations must be assessed before a decision is made. Career decision-making self-efficacy is considered a necessary component of successful career decision-making (Argyropoulou \& Kaliris, 2018). Ahmed and Ahmed (2019) posits that selfefficacy refers to an individual's confidence in their capabilities to accomplish challenges and meet specific goals. It indicates that career certainty is connected with personal beliefs with a career chosen. Individuals with higher compatibility between belief and their preferred career often display greater certainty in their career decision-making, supporting the Social Cognitive Career Theory (SCCT). 


\section{Academic Achievement}

Academic achievement is another important factor for making a career decision at the university level. Academic achievement is one of the leading educational goals. In this study, the researcher measured student's academic achievement from their current CGPA. It is the most common indicator of achievement in academic contexts (Benitez, 2017). According to Abdul Wahab (2017), graduates have used their qualifications to secure jobs and potential career and business growth in their transition from education to settlement in employment. Academic qualifications with high achievement will increase the graduate employability to more career opportunities. Indeed, Mendoza and Hontiveros (2017) stated that academic achievement serves as the primary focus for hiring decisions. Moreover, higher academic achievement will be able to improve self-esteem and confidence during the recruitment and selection process rather than students who have lower academic achievement.

Previous research by Talib and Aun (2009) found that higher success university students have higher levels of indecision and are more uncertain about their careers. This is because they tend to be more concerned about their career options since most of them have not settled on their future careers. Thus, they feel a greater need for self-exploration and career exploration in making career decisions. On the other hand, students who are concern about their future career path will improve their academic performance in order to look for a wide range of career opportunities even though there is uncertainty about the career chosen. It is supported by Kustati et al. (2017) that also found academic achievement has a significant relationship with students' career readiness. Ayodele (2019) suggests that age and academic graduation classification influence the students' choice of a career. Students who have a high level of academic success can have progressive attitudes and a tremendous willingness to build a new career in order to meet their preferred work goals without any switching behaviour. Hence, the current study investigates whether students' CGPA at the undergraduate level impacts their career decision making. In this regard, the surveyed students' CGPA is analysed.

\section{Academic Self-Concept}

Academic self-concept is referred to as students' knowledge and perceptions regarding their levels of competencies on academic skill sets and performance (Cooper et al., 2018). In fact, past research reveals consistent results that suggest having a good self-concept can encourage student engagement, goal-setting, performance and achievement, and career decisions. Interactions in class may be one of the reasons for the differences in academic self-concept levels between students (Cooper et al., 2018). The researchers found that students with higher academic self-concept are more likely to participate actively in class, impacting student learning. This is because research has shown that greater engagement can contribute to greater understanding, as students are generating their knowledge rather than listening passively.

Bounds (2017) also posits that career decision self-efficacy was significantly and positively correlated to academic self-concept among African American adolescents. Similar to the current study, a descriptive study by Hamed et al. (2017) investigating the level of academic self-concept among the pre-diploma students using the Academic Self-concept Scale by Liu and Wang (2005) found most of the students had moderate to a high level of academic effort and academic confidence. Research by Burger and Naudé (2019) shows that academic self-concept explained 
Vol. 10, No. 2, 2021, E-ISSN: 2226-6348 @ 2021 HRMARS

the largest amount of variance during the entry and integration stages of students' academic success were examined. As students feel confident about their talents and achievements, they experience an intensified desire to excel in their studies, resulting in higher exam scores. Moreover, it is useful to understand the mechanisms involved in academic self-concept formation. This may lead to better career decision making. Thus, the interrelationships between academic achievement and academic self-concept among university students examined in these studies will offer useful information to a better understanding of their career decision making.

\section{Social Cognitive Career Theory}

The theory that has been used in this study is Social Cognitive Career Theory (SCCT), developed by Lent, Brown, and Hackett (1994). This theory is based on Bandura's (1986) Social Cognitive Theory (SCT), which provides a theoretical framework to explain the influence of personal and social environmental factors on human behavioural changes and decisions in addition to attributes of one's own behaviour. SCCT claims that people are more likely to seek careers where they are believed to benefit from it. SCCT has also been widely used in the understanding of academic and career development. A study by Bounds (2013) used the SCCT as a theoretical framework to support variables that affect students' career growth. The researcher reported a strong link between career decision-making, ethnic identity, and intellectual selfconcept. Analysis has also shown that students with high GPAs of 3.0 and above have higher academic self-concept levels. Another research by Dewsbury et al. (2019) indicated that students who are confident about keeping a particular GPA or have a specific career might be more likely to consider an active learning environment and manage their time effectively explained by the SCCT. Bounds (2017) has used the framework of SCCT to explain the interaction between career decision self-efficacy and academic self-concept, where it shows a significant relationship between the variables.

In this current study, academic self-concept is about the student's belief of their capabilities in academics. It refers to an individual's perceptions toward their abilities to perform a task that can contribute to a successful performance. Academic achievement is included in this research to evaluate students' academic ability in academic self-concept perceptions. It can prove their confidence and effort in academics. Both independent variables are assumed to help students make a career decision (an outcome expectation) that intends to achieve their future career goals. In sum, this Social Cognitive Career Theory (SCCT) is best to examine whether academic achievement and academic self-concept are able to attain a career decision of undergraduate students in the study.

\section{Method}

This study used a quantitative method to collect the data. G*Power software was used to set the minimum sample size because the researcher did not acquire the exact number of the population. By using this software, the results show that the minimum sample size for the proposed study is $134(n=134)$. Data were collected using an online survey form consists of three sections, which are Section A (demographic profile and academic achievement), Section B (academic self-concept), and Section $C$ (career decision making). The research instrument was developed based on past studies and was modified in accordance with the context of this study. 
Vol. 10, No. 2, 2021, E-ISSN: 2226-6348 @ 2021 HRMARS

Academic self-concept was measured using the Academic Self-Concept Scale (ASC) by Liu and Wang (2005). It has two subscales; academic confidence and academic effort, each with 10 items, which utilised a 5-point Likert scale. The career decision making of the respondents was measured using Career Decision Scale (CDS) (Osipow et al., 1976). The CDS measures one's certainty of educational and occupational choice and the one's uncertainty on it with a 5-point Likert scale.

In this study, the sampling technique used is a two-stage sampling technique, where the first stage is simple random sampling. Six faculties out of 15 faculties in Campus Serdang of Universiti Putra Malaysia were chosen at random using a randomizer. The six faculties are; Faculty of Educational Studies, Faculty of Science, Faculty of Food Science and Technology, Faculty of Human Ecology, Faculty of Design and Architecture, and Faculty of Modern Language and Communication. The second stage is convenience sampling. A survey form link was distributed to final year students of Universiti Putra Malaysia conveniently via WhatsApp and other social media applications. Out of the 182 received surveys, 171 surveys were completely and accurately answered in compliance with the survey criteria set out in the survey sheet and the Google Docs online form.

\section{Results and Discussion \\ The Respondents}

A collection of personal characteristics such as gender, faculty, and current CGPA of the 171 respondents has been examined and presented in the Table 1.

Table 1. Gender, faculty, and current CGPA of final year students in UPM

\begin{tabular}{|l|l|l|}
\hline Items & Frequency & Percentage (\%) \\
\hline Gender: & & \\
Male & 42 & 24.6 \\
Female & 129 & 75.4 \\
Total & 171 & 100.0 \\
\hline Faculty: & & \\
Educational Studies & 32 & 18.7 \\
Science & 28 & 16.4 \\
Human Ecology & 29 & 17.0 \\
Design and Architecture & 30 & 17.5 \\
Modern Language and Communication & 27 & 15.8 \\
Food Science and Technology & 25 & 14.6 \\
Total & 171 & 100.0 \\
\hline Current CGPA: & & \\
$3.75-4.00$ & 38 & 22.2 \\
$3.50-3.74$ & 57 & 33.3 \\
$3.00-3.49$ & 65 & 38.0 \\
$2.25-2.99$ & 10 & 5.9 \\
$2.00-2.24$ & 1 & 0.6 \\
Total & 171 & 100.0 \\
\hline
\end{tabular}


Vol. 10, No. 2, 2021, E-ISSN: 2226-6348 @ 2021 HRMARS

Based on Table 1, this study involved 171 respondents consisting of 129 women $(75.4 \%)$ and 42 men (24.6\%). This gives an overview that female respondent was dominated than man. The number of respondent distribution according to selected faculties are in the range of 25 to 32 respondents. In addition, the table shown indicates that majority of the respondents have middle to high range of CGPA, where the highest number of the respondent, 65 (38\%), have the range of CGPA of $3.00-3.49$.

\section{The Level of Variables}

The first objective of this study is to determine the level of academic self-concept and career decision making among final year students in Universiti Putra Malaysia. In order to achieve the objective, a measure of central tendency was performed to assess all the respective variables using mean and standard deviation. The frequency and percentage of each level of the variable are also expressed in a table together with mean and standard deviation. These levels were classified into three levels; low level (1.00-2.33), moderate level (2.34-3.67), and high level (2.343.67). (3.68-5.00). Table 2 has shown the formula of determination of score value and level as below:

Table 2. The level of academic self-concept and career decision-making

\begin{tabular}{|l|l|l|l|l|l|l|}
\hline \multirow{2}{*}{} & \multicolumn{2}{|l|}{ Academic self-concept } & \multicolumn{3}{l|}{ Career decision-making } \\
\cline { 2 - 7 } & Frequency & Mean & Std. Deviation & Frequency & Mean & Std. Deviation \\
\hline Low & 0 & 3.6275 & .49918 & 37 & 2.8717 & .58193 \\
\hline Moderate & 93 & & & 113 & & \\
\hline High & 78 & & & 21 & & \\
\hline
\end{tabular}

Table 2 describes that majority of the respondents, which were among 93 students (54.4\%), experienced a moderate level of academic self-concept, which also expressed a mean of 3.63 for this level. The other $45.6 \%$, consisting of 78 respondents, showed a high level of academic self-concept, and none of the respondents answered the low level of academic selfconcept. The standard deviation for this variable was 0.499 and the mean value is 3.63. Hence, the findings showed that most of the respondents are confident during their learning experience and willing to offer their effort in academic. Academic self-concept knowledge and understanding students be psychologically prepared to face the challenges ahead, such as making a career decision. Efforts should be made continually to establish academic self-concepts so that students can focus on a better future.

The outcome was consistent with previous research by Hamed et al. (2017), which reported that the level of academic self-concept was moderate to high among students. Students with high self-concept or positive self-concept have some advantages, such as assessing themselves positively and the ability to respond positively to a variety of situations (Cooper et al., 2018). Besides, the students also feel that they are able and skilled, have high achievements, and know their strengths and weaknesses (Wolff et al., 2018). The SCCT also supports this statement whereby the students with a high level of self-efficacy tend to have the desire and 
encouragement to learn, as well as the aspirations for a potential career goal. The students will also see themselves as talented and want to make the best decisions for their future.

As illustrated in Table 2, the moderate level of career decision making was displayed by the majority of the respondents, which were 113 that is $66.1 \%$ of the overall 171 of the respondents for this study. This also shows the majority of the students who have a moderate level of career decision making based on the mean that was 2.872 . There were $37(21.6 \%)$ of the respondents who experienced a low level of career decision making. For the high level of career decision making, shows there were 21 respondents (12.3\%) for that level. The standard deviation for this variable was 0.582 and the mean value is 2.87 . The results demonstrated that some of the students have decided on a career while some may experience career decision-making difficulties.

As Gati et al (1996) taxonomy explained, student preparation, approaches, and additional information to initiate the process of making career decisions are important to minimize the difficulties. It is also supported by Argyropoulou and Kaliris (2018) stated that the young adult was facing a transition period that can lead to career indecision. In addition, the SCCT illustrates that if the students are more compatible with their chosen career, they will display greater certainty in their career decision-making to achieve personal career goals. Hence, based on the statements presented and the findings in Table 2, the students who are satisfied and interested in their field of study may minimize the difficulty of making a career choice.

\section{The Relationship of Variables}

The second and third objectives for this research were to examine the relationships between academic achievement and career decision making as well as the relationships between academic self-concept and career decision making among final year students in the selected faculties of Universiti Putra Malaysia. The analyses were done by the Pearson Correlation by running the collected data in the SPSS. The results collected from the data was shown in the table below.

Table 3. The relationship between academic achievement, academic self-concept and career decision-making

\begin{tabular}{|l|l|l|}
\hline \multicolumn{3}{|c|}{ Correlations } \\
\hline \multirow{3}{*}{ Academic achievement } & Career decision making \\
\hline & Pearson Correlation & .007 \\
\cline { 2 - 3 } & Sig. (2-tailed) & .926 \\
\cline { 2 - 3 } & $\mathrm{N}$ & 171 \\
\hline \multirow{3}{*}{ Academic self-concept } & Pearson Correlation & $.465^{* *}$ \\
\cline { 2 - 3 } & Sig. (2-tailed) & .000 \\
\cline { 2 - 3 } & $\mathrm{N}$ & 171 \\
\hline
\end{tabular}

**. Correlation is significant at the 0.01 level (2-tailed).

The table shown above shows that the relationship between academic achievement and career decision-making does not have any significant correlation. The $r$-value of the variables was 0.007 , and it indicates that academic achievement and career decision-making do not correlate 
significantly, either positive or negative. The significant value $p$ for the variables was .926 ( $p>0.05)$, which portrays no significant correlation between both variables. Thus, the $p$-value is not significant $(p>0.05)$, and the null hypothesis fails to reject. There is no significant relationship between academic achievement and career decision making.

Even though the results do not match with the previous study, such as research by Kustati et al. (2017); Titthasiri (2020), few studies show the same results as this current study. For instance, correlational research by Akter and Siraj (2018) also found that the CGPA of the students is considered an insignificant factor for graduates to pursue career-related in their field of study. So, the current study has contributed to the empirical literature and findings on the relationship between the two variables. The findings also supported previous literature that revealed that career decisions are not related to academic performance (Basammula, 2019). This is because the students who had decided on their career do not mean that they performed in their academic studies relevant to CGPA and vice versa. It could also be due to the reason that most of the respondents who participated in the study mainly belonged to the higher to middle range of academic achievement. Moreover, this was consistent with past literature that SCCT attempts to address the various career development issues and explain crucial, diverse processes and mechanisms whereby career and academic aspirations develop, construct and implement career-related choices and achieve good outcomes. Hence, the relationship between academic achievement and career decision making was proved to have no significant relationship in this research study.

In contrast, as illustrated in the Table 3, there is a significant relationship between academic self-concept and career decision making. From the output, the variable of academic self-concept has a relatively moderate correlation with career decision making $(r=0.465 ; p<0.05$; $\mathrm{n}=171$ ). The Pearson correlation coefficient is positive, meaning if the students portrayed moderate academic self-concept, their career decision making would also be high. Hence, the $p$ value is significant $(p<0.05)$, and the null hypothesis is rejected. In conclusion, there is a positive and moderate relationship between academic self-concept and career decision making.

The results of this study shows that academic self-concept had an impact on career decision making. The SCCT proposed by Lent, Brown, and Hackett (1994) explained that career choices are influenced more directly and potently by self-efficacy beliefs, outcome expectations, or environmental variables. The previous study proves that the learning environment plays a crucial role in academic self-concept (von Keyserlingk et al., 2019). As students posit a positive learning environment and academic self-concept, it will foster career decisions. In addition, the findings show that the student who acquired the belief or confidence that they can perform particular tasks during their university years have the skills to make a career decision. As long as he has faith in himself, each person will achieve the point of self-perfection. Therefore, students who have portrayed a strong self-concept in their final years by handling, conducting, and solving academic problems appear to have high career decision-making skills for their future and comfortable with the choice (Cooper et al., 2018). Thus, it shows that the theory is significantly aligned with this research's findings, where there was a significant positive relationship between the two variables. 


\section{Conclusion}

The results demonstrate that during undergraduates' learning experience, most of the them are confident and willing to offer their effort in academic. Also, some of the students have decided on a career while some experience career decision-making difficulties. This research found that academic self-concept knowledge and understanding help a graduating student prepared to face any challenges ahead, such as making a career decision. Learning behaviour is beneficial to students and the university, to get a clearer view of the student's future following graduation. This research responds to people who have challenged the relevance of the academic sense, as the results demonstrate how students respond favourably to their academic confidence and efforts to make career choices during their final year in university. This study helps the university, company or specialist of human resources to have insights to establish a better working environment for new graduates. Early exposure to this matter will inspire students to study hard and will prevent them from giving up to make their dream come true while they are actively learning. To make the students completely use all the resources provided for a brighter future, the organization needs to be aware of the students' self-concept and improve their current skills and knowledge. Other than that, the study had contributed theoretically. Social Cognitive Career Theory can be used to explain the relationship between the academic selfconcept and career decision making.

\section{Suggestion for Future Research}

The study proposed to extend the size of the population and expand the number of survey respondents to apply the variables of this study for future studies. To diversify, this study's participants should involve final year students from other universities in Malaysia, which would be one of the recommendations. It helps create samples that fully represent the population and make the results more accurate. Apart from that, it is advisable to provide an in-depth understanding of the relationship between academic achievement and academic self-concept and career decision-making by conducting a qualitative method. It can help the research be more comprehensive. It provides insights into students' learning behaviour in detail, and the specific academic activities or behaviours impacted students' career choice. By doing that, the findings of this research may be more precise and more specialized for students to gain from it.

This study only identified the level of academic self-concept and career decision-making and the significant relationship between students' academic self-concept and career decisionmaking. Thus, further research is recommended to examine other academic or non-academic factors other than the variables that have been conducted-for instance, social involvement, institution involvement, and learning habits effects on career decision making. Lastly, the studies may add to the empirical literature on career development and benefit future researchers as a reference or guide.

\section{Authors Contribution}

The author(s) affirmed that there is no conflict of interest in this article. Author 1 work on theoretical and contextual contribution, Author 2 and 3 carried out the fieldwork, prepared the literature review and overlook the write up the article. Author 1 and 3 wrote the research 
Vol. 10, No. 2, 2021, E-ISSN: $2226-6348$ @ 2021 HRMARS

methodology and Author 2 the data entry. Author 3 carried out the statistical analysis and interpretation of the results.

\section{References}

Abdul Wahab, D. B. (2017). Graduate labour market analysis in Malaysia (Unpublished Doctoral dissertation), University of Leeds.

Abdullah, N., Hussin, N., Shonubi, O. A., Ghazali, S. R., \& Talib, M. A. (2018). Career decisionmaking competence, self-knowledge, and occupational exploration: a model for university students. Journal of Technical Education and Training, 10(1).

Ahmed, N. O. A., \& Ahmed, A. (2019). Career commitment: the role of self-efficacy, career satisfaction and organizational commitment. World Journal of Entrepreneurship, Management and Sustainable Development.

Akter, M., \& Siraj, M. M. (2018). Factors Affecting Undergraduate Students' Intention to Become a Chartered Accountant in Bangladesh. Asian Journal of Finance \& Accounting, 10(1), 428439.

Argyropoulou, K., \& Kaliris, A. (2018). From career decision-making to career decisionmanagement: New trends and prospects for career counseling. Advances in Social Sciences Research Journal, 5(10).

Ayodele, T. O. (2019). Career choice of real estate students in Nigeria. Property Management.

AAM Rami, R., Abdullah, A. I. (2016). The community leaders as a catalyst for rural community development in the state of Terengganu. International Journal of Academic Research in Business and Social Sciences. 6(12). 2222

Basammula, C. (2019). Self-concept, career choice and academic performance among students of Makerere Highway College School(Unpublished Doctoral dissertation), Makerere University.

Benitez, J. D. (2017). Relationships among Behavioral Engagement, Self-Efficacy, Academic Achievement, and Career Choice among Middle School Mathematics Students: Race and Gender Differences.

Bounds, P. S. (2013). Examining the relationship between career decision self-efficacy, ethnic identity, and academic self-concept and achievement of African American high school students.

Bounds, P. S. (2017). Contextual factors related to African American adolescent career development. The Career Development Quarterly, 65(2), 131-144.

Burger, A., \& Naudé, L. (2019). Predictors of academic success in the entry and integration stages of students' academic careers. Social Psychology of Education, 22(3), 743-755.

Cooper, K. M., Krieg, A., \& Brownell, S. E. (2018). Who perceives they are smarter? Exploring the influence of student characteristics on student academic self-concept in physiology. Advances in physiology education, 42(2), 200-208.

Dewsbury, B. M., Taylor, C., Reid, A., \& Viamonte, C. (2019). Career choice among firstgeneration, minority STEM college students. Journal of microbiology \& biology education, 20(3).

Gati, I., Levin, N., \& Landman-Tal, S. (2019). Decision-making models and career guidance. In International handbook of career guidance (pp. 115-145). Springer, Cham. 
Hamed, S., Hussin, F., \& Jam, S. M. (2017). Academic self-concept among the pre diploma students. International Academic Research Journal of Social Science, 3(1), 128-134.

Jang, H. J., \& Lee, J. H. (2020). The Effects of Social Support and Career Decision-Making SelfEfficacy on Job-Seeking Stress among Nursing Students. Journal of Convergence for Information Technology, 10(9), 62-70.

Krannich, M., Goetz, T., Lipnevich, A. A., Bieg, M., Roos, A. L., Becker, E. S., \& Morger, V. (2019). Being over-or underchallenged in class: Effects on students' career aspirations via academic self-concept and boredom. Learning and Individual Differences, 69, 206-218.

Kustati, M., Zulfikar, T., \& Hallen, H. A. A. (2017). The Contribution of Undergraduate Students' Self-Esteem and Academic Achievement to Their Career Readiness. International Journal of Latest Research in Humanities and Social Science, 3(1).

Levin, N., Braunstein-Bercovitz, H., Lipshits-Braziler, Y., Gati, I., \& Rossier, J. (2020). Testing the structure of the Career Decision-Making Difficulties Questionnaire across country, gender, age, and decision status. Journal of Vocational Behavior, 116, 103365.

Mamat, N., Rami A. M., Abdullah, R., Simin, M. H. (2019). Malay Language Teaching and Learning Strategies among Orang Asli Students in Terengganu. International Journal of Recent Technology and Engineering. 8 (1c2), 1158 - 1168

Mendoza, H., \& Hontiveros, E. P. (2017). Academic achievement, emotional intelligence and fluid intelligence as predictors of intrinsic career success of graduate students: Basis for career development program. Asian Journal of Social Sciences and Humanities, 6(1), 9-20.

Rami, A. M., Aziz, F., Razali, F., \& Ibrahim, A. (2020). Effective local leadership to a successful council in the state of Terengganu, Malaysia. International Journal of Advanced Science and Technology, 29(7), 205-210.

Rami, A. M., Abdullah, R., \& Ariffin, W. J. (2018). Strengthening social capital: Local leader's strategy toward developing rural community. International Journal of Academic Research in Business and Social Sciences, 8(1), 765-774.

Rami, A. M., Mamat, N., Abdullah, R., \& Simin, H. A. (2018). The local leaders strategy to empowering rural youth in Malaysia: a qualitative study. National Academy of Managerial Staff of Culture and Arts Herald, (1).

Storme, M., \& Celik, P. (2018). Career exploration and career decision-making difficulties: The moderating role of creative self-efficacy. Journal of Career Assessment, 26(3), 445-456.

Talib, M. A., \& Aun, T. K. (2009). Predictors of career indecision among Malaysian undergraduate students. European Journal of Social Sciences, 8(2), 215-224.

Titthasiri, W. (2020). An Impact of CS Undergraduate Programming Skill on Career Development. International Journal of Computer Science and Software Engineering, 9(3), 60-63.

Wolff, F., Nagy, N., Helm, F., \& Möller, J. (2018). Testing the internal/external frame of reference model of academic achievement and academic self-concept with open self-concept reports. Learning and Instruction, 55, 58-66. 